\title{
FRICTION-STIR PROCESSING OF A COMPOSITE ALUMINIUM ALLOY (AA 1050) REINFORCED WITH TITANIUM CARBIDE POWDER
}

\author{
UPORABA MEŠANJA S TRENJEM ZA IZDELAVO KOMPOZITA \\ ALUMINIJEVE ZLITINE (AA1050), OJAČANE S TITANOVIM \\ KARBIDOM V PRAHU
}

\author{
Kazeem Oladele Sanusi, Esther Titilayo Akinlabi \\ University of Johannesburg, Department of Mechanical Science, Auckland Park Kingsway Campus, Johannesburg 2006, South Africa \\ sanusik@gmail.com
}

Prejem rokopisa - received: 2016-01-22; sprejem za objavo - accepted for publication: 2016-05-20

doi:10.17222/mit.2016.021

\begin{abstract}
In this study the friction-stir processing (FSP) technique was applied for the development of surface composites of aluminium alloy (AA 1050) reinforced with titanium carbide (TiC) powder of particle size range below $60 \mu \mathrm{m}$ compressed into the groove. Rotational speeds of $1200 \mathrm{~min}^{-1}$ and $1600 \mathrm{~min}^{-1}$ and the travel rates of $(100,200$ and 300$) \mathrm{mm} / \mathrm{min}$ were used for the process. This study investigates the effect of processing parameters on the wear-resistance behavior of friction-stir processed Al-TiC composites. This was achieved through microstructural characterization using optical and scanning electron (SEM) microscopes equipped with Oxford energy-dispersion spectrometry (EDS) (Tescan), microhardness profiling and wear resistance tests. From the results, it was found that the processing parameters influenced the distribution of the TiC particles. The microhardness profiling of the processed samples revealed an increase in the hardness value compared to the parent material. The wear-resistance test results confirmed the FSP technique enhanced properties in surface engineering.
\end{abstract}

Keywords: aluminium alloy, friction-stir processing, microhardness, microstructure, surface composite, TiC

V študiji je bila uporabljena tehnika mešanja s trenjem (angl. FSP) za razvoj površinskih kompozitov iz aluminijeve zlitine (AA 1050), ojačanih s titanovim karbidom (TiC) v prahu, z velikostjo delcev v območju pod $60 \mu \mathrm{m}$, stisnjenih v utor. Pri tem postopku so bile uporabljene hitrosti vrtenja $1200 \mathrm{~min}^{-1}$ in $1600 \mathrm{~min}^{-1}$ in hitrosti pomikanja (100, 200 in 300) mm/min. Studija raziskuje vpliv procesnih parametrov na odpornost kompozitov $\mathrm{Al}-\mathrm{TiCi}$ proti obrabi s trenjem. Izvedena je bila mikrostrukturna karakterizacija z uporabo svetlobnega in vrstičnega elektronskega mikroskopa (SEM), opremljenega z Oxford energijsko disperzijsko spektrometrijo (EDS) (Tescan), profiliranja mikrotrdote in preizkusa obrabe. Iz rezultatov je bilo ugotovljeno, da so parametri obdelave vplivali na distribucijo TiC delcev. Profiliranje mikrotrdote na vzorcih je pokazalo, da je vrednost trdote povečana v primerjavi z osnovnim materialom. Rezultati testa odpornosti obrabe so potrdili, da FSP-tehnika izboljša lastnosti površine.

Ključne besede: aluminijeve zlitine, tehnika mešanja s trenjem, mikrotrdota, mikrostruktura, površinski kompoziti, TiC

\section{INTRODUCTION}

Friction-stir processing (FSP) is a newly emerging technology based on the friction-stir welding (FSW) method that allows the near-surface regions of a material to be selectively processed and currently used to enhance the mechanical properties of conventional materials. ${ }^{1}$ This process has been applied to microstructural modifications for enhanced mechanical properties through intense plastic deformation using a non-consumable rotating tool that causes material mixing and thermal exposure and results in grain refinement of the material being processed. ${ }^{2,3}$ The benefits of the FSP process include significant microstructural refinement, densification, and homogeneity of the processed zone, homogenization of precipitates in various aluminium alloys and composite materials. ${ }^{4-6}$ Moreover, the severe plastic deformation (SPD) and material flow in the stirred zone of the FSP can be utilized to achieve surface or bulk alloy modification by the mixing of other elements into the stirred alloys where the stirred material can become a metal matrix composite or an intermetallic alloy with much higher hardness and good wear-resistance properties. $^{7}$ Applications of the FSP/FSW are widespread for the aerospace, automotive and the transportation industries. Research studies have been reported on the friction-stir process that grain refinement can be achieved in this way. The microstructure and mechanical behaviour of lightweight materials subjected to the FSW/FSP are being studied extensively, which include the processing of the microstructure amenable to highstrain-rate superplasticity. ${ }^{8}$ Y. Kwon et al. produced 1050 aluminium alloy with an ultra-fine grain size through the friction-stir process (FSP). They studied the influence of tool rotation speed on the temperature profile, microstructure and mechanical properties of the friction-stir processed zone (FZ) and they concluded that FSP is very effective in producing an ultra-fine-grained material with excellent mechanical properties. 
Aluminium matrix composites (AMCs) reinforced with ceramic particles exhibit high strength, high elastic modulus, and improved resistance to wear, creep and fatigue, which make them promising structural materials for aerospace and automobile industries. ${ }^{9}$ These composites can suffer a great loss in ductility and toughness due to the incorporation of non-deformable ceramic reinforcements, which limits their wide applications to a certain extent. ${ }^{10,11}$ However, the nature of the technique used to fabricate particle-reinforced metal-matrix composites (MMCs) has been shown to have a significant effect on the product's mechanical properties and hence the applications for which it is suitable. ${ }^{12-15}$ Surfacemodification techniques such as high-energy laser beam, plasma spraying, cast sinter and electron beam irradiation have been developed over the past two decades to fabricate Surface Metal Matrix Composites (SMMCs). ${ }^{16-19}$ It has been shown that friction-stir processing (FSP) can be effectively used to homogenise the particle distribution in Al-based in-situ composites. R. Mishra et al. ${ }^{12}$ confirmed the application of FSP technology to fabricate AA5083/SiC SMMC. The incorporation of $\mathrm{SiC}$ particles on the surface was successful and bonded well with the matrix. Subsequently, they confirmed FSP as a promising method to fabricate SMMCs. ${ }^{2}$ Mahmoud et al. fabricated AA1050/SiC SMMC, their results showed that the distribution of the $\mathrm{SiC}$ particles became more homogeneous with an increasing number of passes and with the combination of tool rotational speed and the processing speed resulted in the formation of defects, such as voids and tunnels in the FSP zone. ${ }^{20}$ E. R. I. Mahmoud et al. ${ }^{20}$ also fabricated AA1050/SiC SMMC and assessed the effect of the tool pin size and profile. From their results, the wear rates of the samples produced with the flat surface tools were higher than that of the samples produced with the round-shaped tools and the samples produced with the square profile pin yielded a finer distribution of the $\mathrm{SiC}$ particles. ${ }^{21}$ R. Bauri et al. ${ }^{22}$ used FSP effectively to homogenise the particle distribution in Al-based in-situ composites. The process was employed on the as-cast composite to uniformly distribute the $\mathrm{TiC}$ particles in the Al matrix. The composite was subjected to single- and double-pass FSP and its effect on the microstructure and properties was evaluated. From their results, they confirmed that a single pass of FSP was enough to break the particle segregation from the grain boundaries and improve the distribution and two passes of FSP resulted in complete homogenization and elimination of casting defects. The grain size was also refined after each FSP pass. This led to a significant improvement in the mechanical properties after FSP. A. Kahrizsangi and S. Kashani-Bozorg ${ }^{23}$ works on a mild-steel substrate by the introduction of nano-sized TiC powder into the stir zone using four passes of friction stir processing and the TiC clusters were formed after the first pass. Sequential break-up of the clusters and refinement of the matrix grains were caused by subsequent FSP passes. A nearuniform dispersion of nano-sized TiC particles was achieved after the fourth pass. A significant improvement in the wear resistance of the nano-composite layer was observed as compared to that of the as-received substrate and the enhanced properties are attributed to the uniform dispersion of hard nano-sized TiC reinforcements in a matrix of ultra-fine dynamically recrystallized grains. A. Thangarasu et al. ${ }^{10}$ fabricated $\mathrm{TiC}$ particulates $(\approx 2 \mu \mathrm{m})$ and reinforced them with an aluminium matrix composite (AMC) using FSP. The powders were compacted into a groove and a single pass FSP was carried out using a tool rotational speed of $1600 \mathrm{~min}^{-1}$ and a processing speed of $60 \mathrm{~mm} / \mathrm{min}$. They analysed the microstructure and microhardness of the fabricated AMC and from their results, revealed a uniform distribution of $\mathrm{TiC}$ particles which were well bonded to the matrix alloy with an increase in the hardness value of the AMC compared to that of the matrix alloy. E. Akinlabi et al. ${ }^{3}$ investigated the effect of the processing parameters on the wear-resistance behaviour of friction-stir processed Al-TiC composites. From their findings it was revealed that an increase in the hardness value, which was a function of the TiC particles incorporated when compared to the parent material and the wear resistance property, was also found to increase as a result of the $\mathrm{TiC}$ powder addition. The right combination of the processing parameters was found to improve the wear resistance property of the composites produced. Kurt et al. incorporated $\mathrm{SiC}$ particles into the commercially pure aluminium to form particulate surface layers by using friction-stir processing (FSP). The samples were subjected to the various tool rotating and traverse rates with and without $\mathrm{SiC}$ powders. Microstructural observations were carried out by employing optical microscopy of the modified surfaces. Mechanical properties like hardness and plate bending were investigated. The results showed that increasing rotating and traverse rate caused a more uniform distribution of the $\mathrm{SiC}$ particles. Uygur studied commercially pure $(\mathrm{CP})$ aluminium using the friction stir welding technique (FSW) to weld the specimens. The welding process was carried out by rotating $1500 \mathrm{~min}^{-1}$ and by moving $200 \mathrm{~mm} / \mathrm{min}$. Under a constant friction force this involved four different shoulder diameters of $(20,25,30$ and 40) $\mathrm{mm}$. During welding, temperature measurements were performed using a non-contact laser thermometer at various parts of the plates from the welding centre outwards. Microscopic and mechanical tests were used to characterize the sample.

In this paper, a further research study was conducted on AA1050 to uniformly distribute the TiC particles into the Al matrix using friction stir processing. The produced composites were investigated through the microstructural evolution, wear resistance behaviour and the hardness distribution. The research study is aimed at providing a better understanding of the materials behaviour 
K. O. SANUSI, E. T. AKINLABI: FRICTION-STIR PROCESSING OF A COMPOSITE ALUMINIUM ALLOY (AA 1050) ...

after FSP using different combinations of rotational speeds and travel rates.

\section{MATERIALS AND METHODS}

In this study, aluminium alloys (AA1050) with rectangular elements with dimensions of $(200 \times 160 \times 3)$ $\mathrm{mm}$ were used for this experiment. The experimental setup showing the clamping fixture and the backing plate system is presented in Figure 1. The chemical composition of the aluminium alloy used is presented in Table 1. The V-groove of about $5 \mathrm{~mm}$ was machined and filled with $\mathrm{TiC}$ powder with the aim of strengthening the material. Some $99.5 \% \mathrm{TiC}$ with a particle size range below $60 \mu \mathrm{m}$ ball milled powder with irregular shape was used. The powder was compressed into the groove using a pinless tool across the surface of the material and

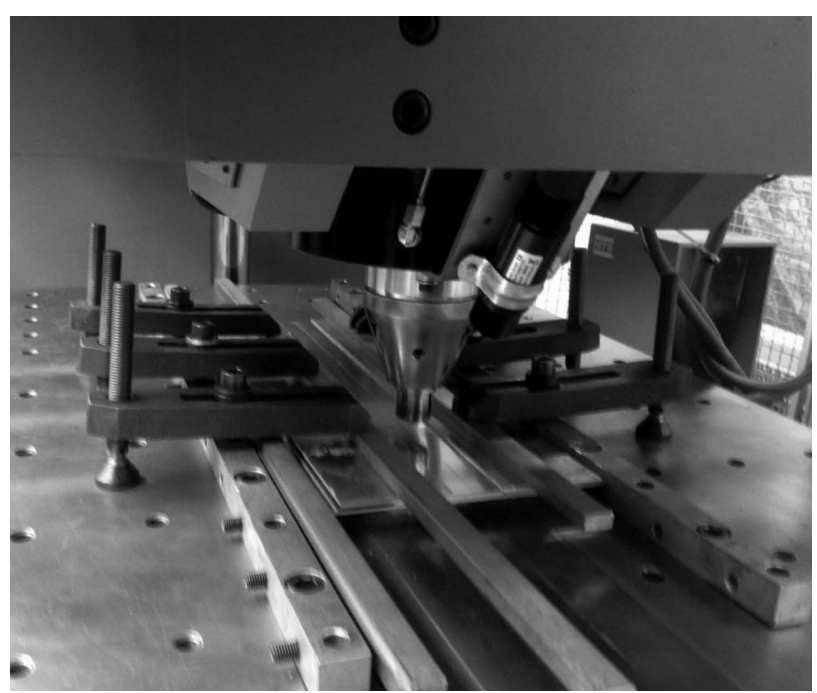

Figure 1: Experimental set up Slika 1: Experimentalni sestav

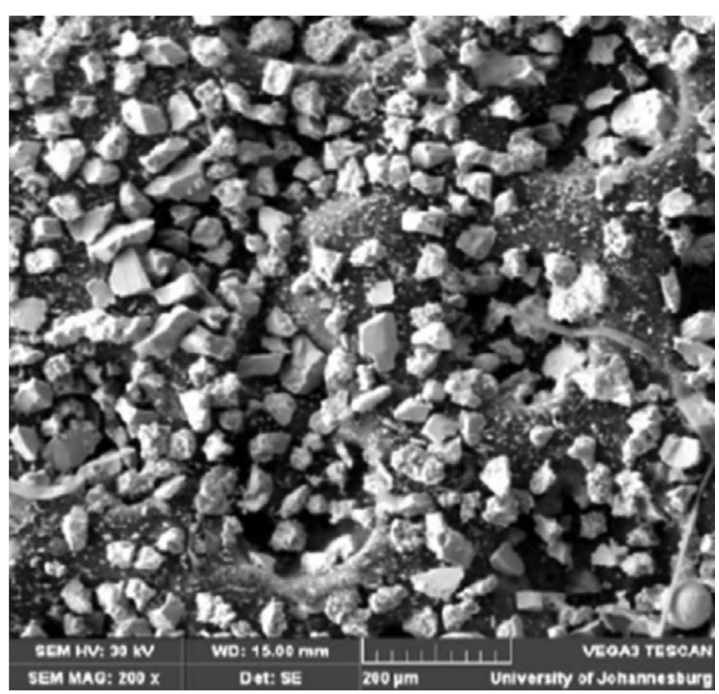

Figure 2: SEM micrograph of the titanium carbide powder Slika 2: SEM-posnetek prahu titanovega karbida a second tool, comprising a pin and shoulder, was plunged into the workpiece after compressing the $\mathrm{TiC}$ powder. The micrograph of the $\mathrm{TiC}$ powder used is shown in Figure 2. The tools were machined from H13 tool steel and hardened to $52 \mathrm{HRC}$. The workpieces were securely clamped on a rigid, smooth, mild-steel backing plate with dimensions of $(650 \times 265 \times 25) \mathrm{mm}$, to make the material withstand the significant perpendicular and lateral forces developed during the friction-stir process. The weld matrix employed with the processing parameters is presented in Table 2 . The rotational speeds employed were $1200 \mathrm{~min}^{-1}$ and $1600 \mathrm{~min}^{-1}$ and the travel rates were $(100,200$ and 300$) \mathrm{mm} / \mathrm{min}$, both representing the low, medium, and high settings, respectively. Figure 3 shows a schematic drawing of the V-groove machined into the base metal.

Table 1: Chemical composition of AA1050 Tabela 1: Kemijska sestava zlitine AA1050

\begin{tabular}{|c|c|c|c|c|c|c|c|c|}
\hline & $\mathrm{Al}$ & $\mathrm{Si}$ & $\mathrm{Fe}$ & $\mathrm{Cu}$ & $\mathrm{Mn}$ & $\mathrm{Mg}$ & $\mathrm{Zn}$ & $\mathrm{V}$ \\
\hline AA1050 & 99.5 & 0.25 & 0.4 & 0.05 & 0.05 & 0.05 & 0.05 & 0.05 \\
\hline
\end{tabular}

Table 2: Processing-parameters matrix of friction-stir processing

Tabela 2: Matrika procesnih parametrov pri obdelavi mešanja s trenjem

\begin{tabular}{|c|c|c|}
\hline Designation & $\begin{array}{c}\text { Spindle speed } \\
\left(\mathrm{min}^{-1}\right)\end{array}$ & $\begin{array}{c}\text { Travel rate } \\
(\mathrm{mm} / \mathrm{min})\end{array}$ \\
\hline FsP 1200_100 & 1200 & 100 \\
\hline FsP 1200_200 & 1200 & 200 \\
\hline FsP 1200_300 & 1200 & 300 \\
\hline FsP 1600_100 & 1600 & 100 \\
\hline FsP 1600_200 & 1600 & 200 \\
\hline FsP 1600_300 & 1600 & 300 \\
\hline
\end{tabular}
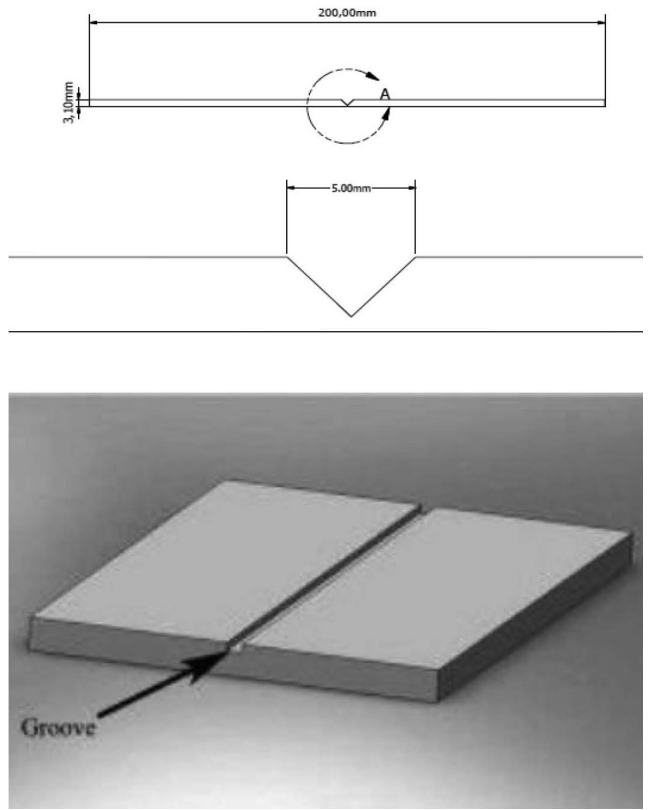

Figure 3: A schematic drawing showing the V-groove machined into the base metal

Slika 3: Shematski prikaz in posnetek klinastega utora $\mathrm{v}$ osnovni kovini 


\section{MATERIALI IN TEHNOLOGIJE/MATERIALS AND TECHNOLOGY (1967-2017) - 50 LET/50 YEARS}

K. O. SANUSI, E. T. AKINLABI: FRICTION-STIR PROCESSING OF A COMPOSITE ALUMINIUM ALLOY (AA 1050) ...

All the processed samples and the as-received materials were cut into the required sample sizes with the aid of the water-jet cutting technique for microstructural characterization and microhardness measurements. The processed specimens were examined with a scanning electron microscope (SEM) equipped with Oxford energy-dispersion spectrometry (EDS) (Tescan) were used to characterize the samples. The microhardness measurements were conducted using a Vickers microhardness tester with a diamond indenter using $300 \mathrm{~g}$ load and a dwell time of $15 \mathrm{~s}$ at the surface of the processed samples and the parent material. The wear tests were evaluated on both the as-received and processed samples using a tribometer (CETRUMT200). The wear resistance test was performed under dry condition using a ball-on-disk arrangement on both the parent material and the materials processed by FSP. The material of the ball is a tungsten carbide of $10 \mathrm{~mm}$ diameter and at a load of $25 \mathrm{~N}$ with a reciprocating frequency of $20 \mathrm{~Hz}$ and for a $2000 \mathrm{~m}$ sliding distance.

\section{RESULTS AND DISCUSSIONS}

\subsection{Surface appearance characterisation}

Figure 4 shows the upper surface appearances of the samples processed at a rotational speed of $1200 \mathrm{~min}^{-1}$ and travel rates of $100 \mathrm{~min} / \mathrm{min}$ and $300 \mathrm{~min} / \mathrm{min}$ and Figure 5 shows the appearance of samples processed at a rotational speed of $1600 \mathrm{~min}^{-1}$ and travel rates of 100 $\mathrm{min} / \mathrm{min}$ and $300 \mathrm{~min} / \mathrm{min}$. From the figures, good smooth and quality surfaces were observed after the FSP, the groove is effectively bonded and no defects such as voids and cracks were observed on the surface. Figure 6 shows the root of sample $\mathrm{C}$ at a rotational speed of 1200 $\mathrm{min}^{-1}$ and a travel rate of $300 \mathrm{~min} / \mathrm{min}$. The root indicates that a thorough stirring was achieved during the FSP.

\subsection{Microstructural evolution}

Figures 7 and $\mathbf{8}$ show the SEM micrographs of the distribution of the TiC particles in the AA 1050 aluminium produced at rotational speeds of $1200 \mathrm{~min}^{-1}$ and $1600 \mathrm{~min}^{-1}$, respectively. Figure 7 shows that the grains in the FSP zone of the specimen were refined; this caused a high plastic strain in the stirred zone in which

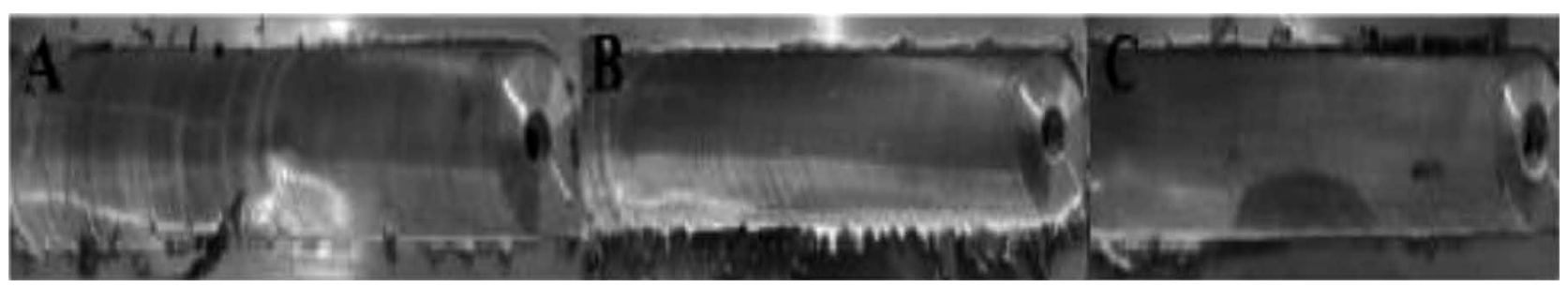

Figure 4: Photograph of samples processed at a rotational speed of $1200 \mathrm{~min}^{-1}$ and travel rates of: a) $\left.100 \mathrm{~mm} / \mathrm{min}, \mathrm{b}\right) 200 \mathrm{~mm} / \mathrm{min}$ and c) $300 \mathrm{~mm} / \mathrm{min}$

Slika 4: Fotografija vzorcev, obdelanih pri vrtilni hitrosti $1200 \mathrm{~min}^{-1}$ in hitrosti pomikanja: a) $100 \mathrm{~mm} / \mathrm{min}$, b) $200 \mathrm{~mm} / \mathrm{min}$ in c) $300 \mathrm{~mm} / \mathrm{min}$

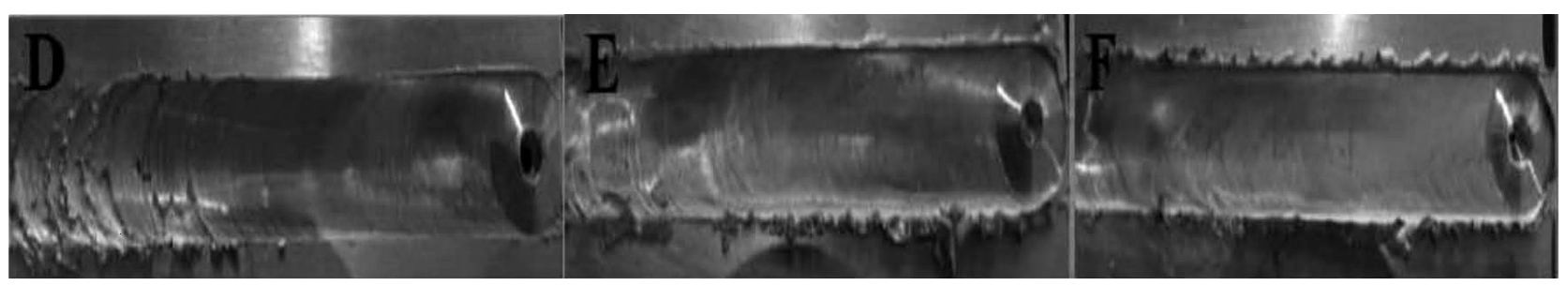

Figure 5: Photograph of samples processed at a rotational speed of $1600 \mathrm{~min}^{-1}$ and travel rates of: d) $100 \mathrm{~mm} / \mathrm{min}$, e) $200 \mathrm{~mm} / \mathrm{mm}$ and f) $300 \mathrm{~mm} / \mathrm{min}$

Slika 5: Fotografija vzorcev obdelanih pri hitrosti vrtenja $1600 \mathrm{~min}^{-1}$ pri hitrosti pomikanja: d) $100 \mathrm{~mm} / \mathrm{min}$, e) $200 \mathrm{~mm} / \mathrm{mm}$ in f) $300 \mathrm{~mm} / \mathrm{min}$

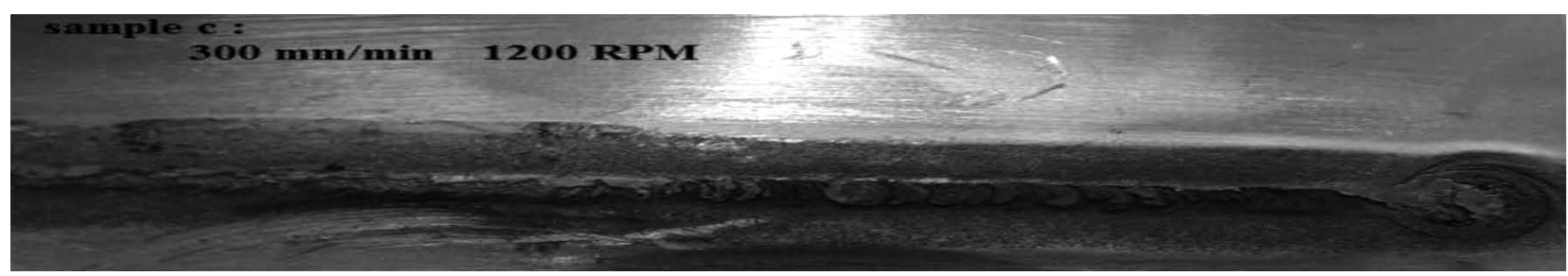

Figure 6: The root of sample C produced at a rotational speed of $1200 \mathrm{~min}^{-1}$ and travel rate of $300 \mathrm{~mm} / \mathrm{min}$

Slika 6: Koren vzorca C, obdelanega pri hitrosti vrtenja $1200 \mathrm{~min}^{-1}$ pri hitrosti pomikanja $300 \mathrm{~mm} / \mathrm{min}$ 
K. O. SANUSI, E. T. AKINLABI: FRICTION-STIR PROCESSING OF A COMPOSITE ALUMINIUM ALLOY (AA 1050) ...
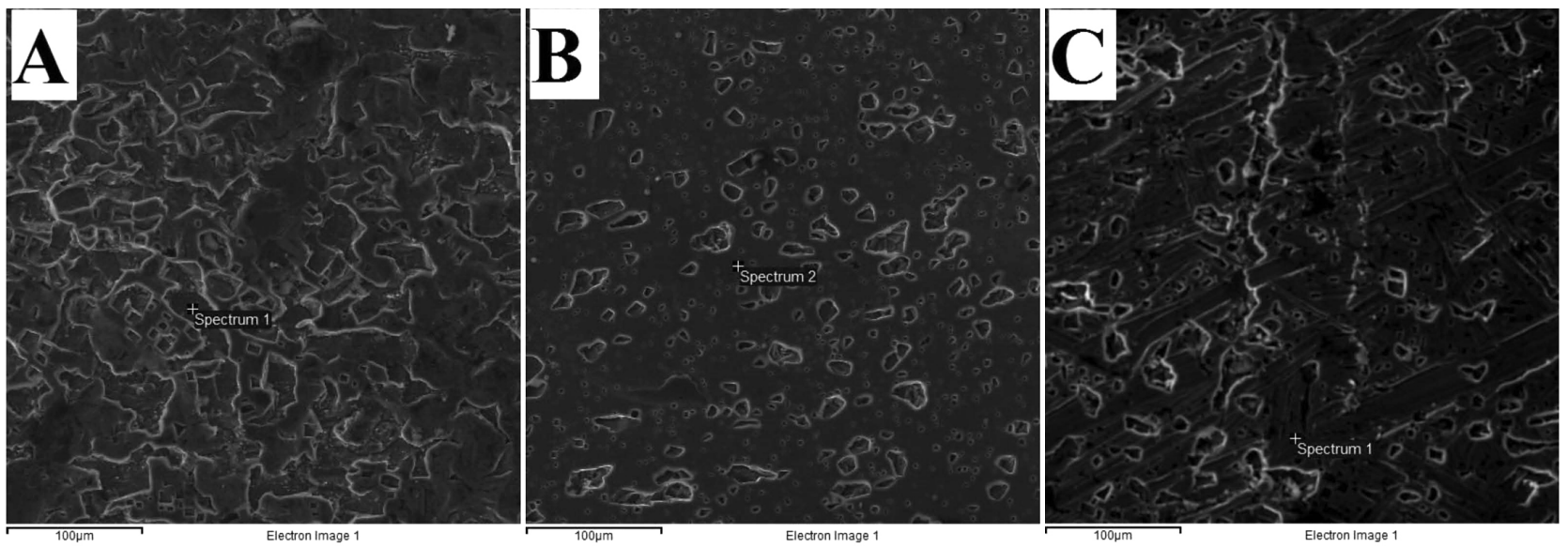

Figure 7: SEM photograph of grains after processing at a rotational speed of $1200 \mathrm{~min}^{-1}$ and travel rates of: a) $100 \mathrm{~mm} / \mathrm{min}$, b) $200 \mathrm{~mm} / \mathrm{min}$, c) $300 \mathrm{~mm} / \mathrm{min}$

Slika 7: SEM-posnetek zrn po obdelavi s hitrostjo vrtenja $1200 \mathrm{~min}^{-1}$ in hitrostjo pomikanja: a) $100 \mathrm{~mm} / \mathrm{min}$, b) $200 \mathrm{~mm} / \mathrm{min}$,c) $300 \mathrm{~mm} / \mathrm{min}$

severe plastic deformation was introduced into the workpiece through the rotating pin and shoulder, which results in a redistribution of the TiC particles. This can be attributed to the heat generated by the tool rotation speed and the traverse speed that resulted in lots of dilution of the $\mathrm{TiC}$ and the Al. A homogenous distribution of the TiC particles is essential to attain higher mechanical properties in the composite of aluminium alloy (AA 1050) and the TiC. The mechanism of grain refinement in AA1050 is that of dynamic recrystallization. $^{22,24}$ It was observed in Figure 7 that the $\mathrm{TiC}$ particles were clustered together at a rotational speed of $1200 \mathrm{~min}^{-1}$ and a travel rate of $100 \mathrm{~min} / \mathrm{min}$ compared to the samples produced at travel rates of $200 \mathrm{~mm} / \mathrm{min}$ and $300 \mathrm{~mm} / \mathrm{min}$. This indicates that when the travel is at a slower rate, the $\mathrm{TiC}$ particles are not well distributed. It was observed in Figure 8 that the size of the TiC particles is not uniform throughout the FSP zone. It was observed that some of the TiC particles were clustered in the samples produced at a high rotational speed of 1600 rpm. This can be attributed to the elevated temperature generated by the tool rotation speed and the traverse speed employed, which is in agreement with the published literature, as reported in some work by researchers in aluminium matrix composites. ${ }^{25-27}$ Particles other than the $\mathrm{TiC}$ and aluminium were also observed in the processed specimens, using energy-dispersive X-ray spectroscopy (EDS).

\subsection{Energy-dispersive X-ray spectroscopy (EDS)}

Energy-dispersive X-ray spectroscopy (EDS) analysis was conducted to evaluate the morphological features of the debris found in the processed specimens. Figure 9 shows the EDS of the debris of an FSP specimen processed at rotational speeds of $1200 \mathrm{~min}^{-1}$ and $1600 \mathrm{~min}^{-1}$. The EDS pattern, shown in the figures, reveals that some particles are comprised of elements like $\mathrm{Si}, \mathrm{C}, \mathrm{Fe}$ and Ag. The presence of these elements indicates that the debris consist of elements present in the tool as well as in the backing plate (e.g., Fe, C). The figures also reveals that the extent of elements like $\mathrm{Si}, \mathrm{C}, \mathrm{Fe}$ and $\mathrm{Ag}$ are
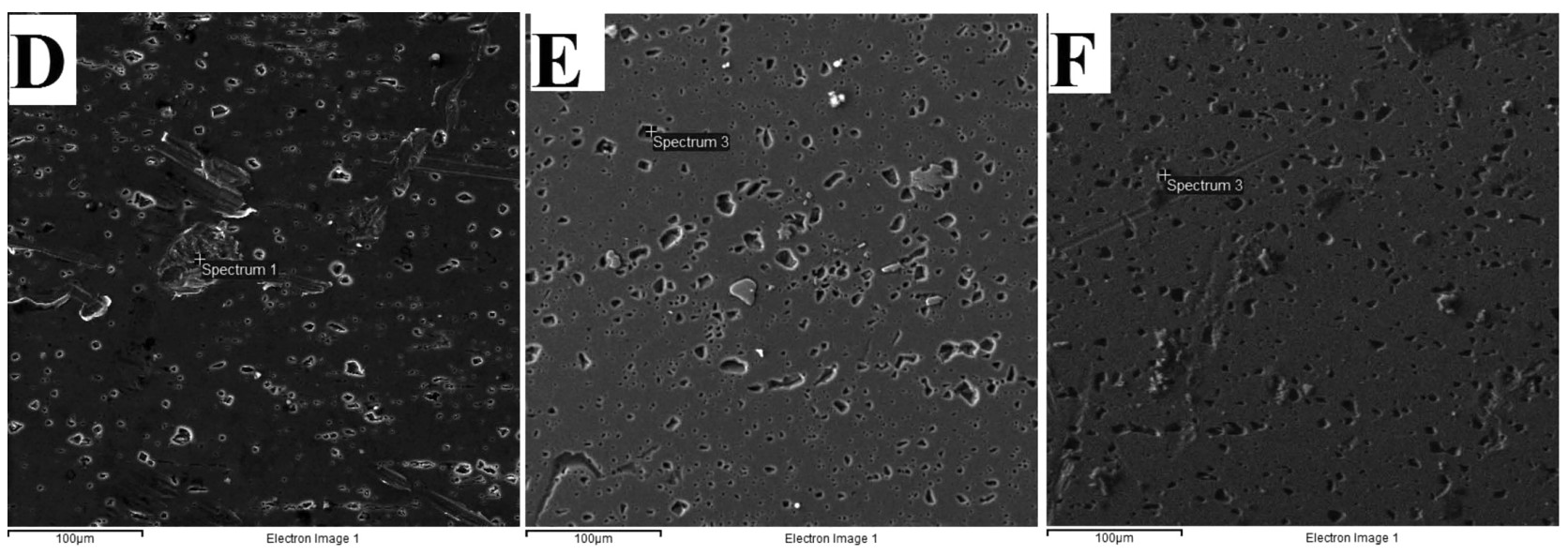

Figure 8: SEM photograph of grains after processing at a rotational speed of $1600 \mathrm{~min}^{-1}$ and travel rates of: d) $100 \mathrm{~mm} / \mathrm{min}$, e) $200 \mathrm{~mm} / \mathrm{min}$, f) $300 \mathrm{~mm} / \mathrm{min}$

Slika 8: SEM-posnetek zrn po obdelavi s hitrostjo vrtenja $1600 \mathrm{~min}^{-1}$ in hitrostjo pomikanja: d) $100 \mathrm{~mm} / \mathrm{min}$, e) $200 \mathrm{~mm} / \mathrm{min}$, f) $300 \mathrm{~mm} / \mathrm{min}$ 
K. O. SANUSI, E. T. AKINLABI: FRICTION-STIR PROCESSING OF A COMPOSITE ALUMINIUM ALLOY (AA 1050) ...
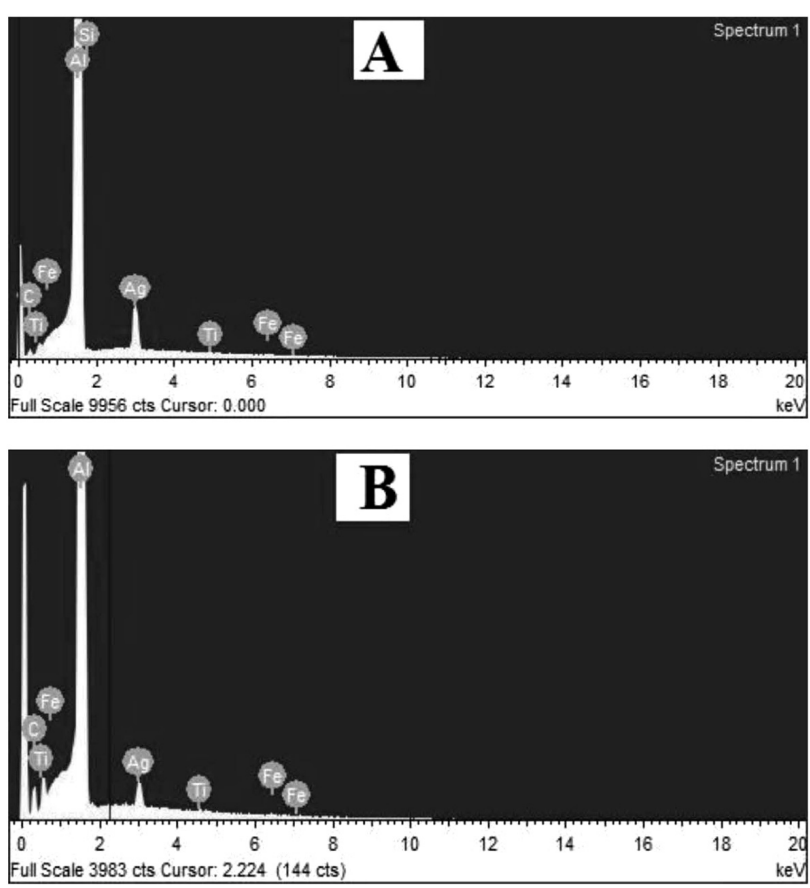

Figure 9: EDS of debris of FSP specimen processed at rotational speed of: a) $1200 \mathrm{~min}^{-1}$ and b) $1600 \mathrm{~min}^{-1}$

Slika 9: EDS-zlomnine iz FSP vzorca, obdelanega s hitrostjo vrtenja: a) $1200 \mathrm{~min}^{-1}$ in b) $1600 \mathrm{~min}^{-1}$

present in the specimen, which implies that the worn out particles/debris mainly result from the tools/backing plate and/or dissociation of the TiC. However, tool-wear debris is inevitable during FSW/FSP and reported in the FSP specimen layers in a scattered fashion by A. Kahrizsangi and S.vKashani-Bozorg and Y. Wang et. al. ${ }^{23,28}$

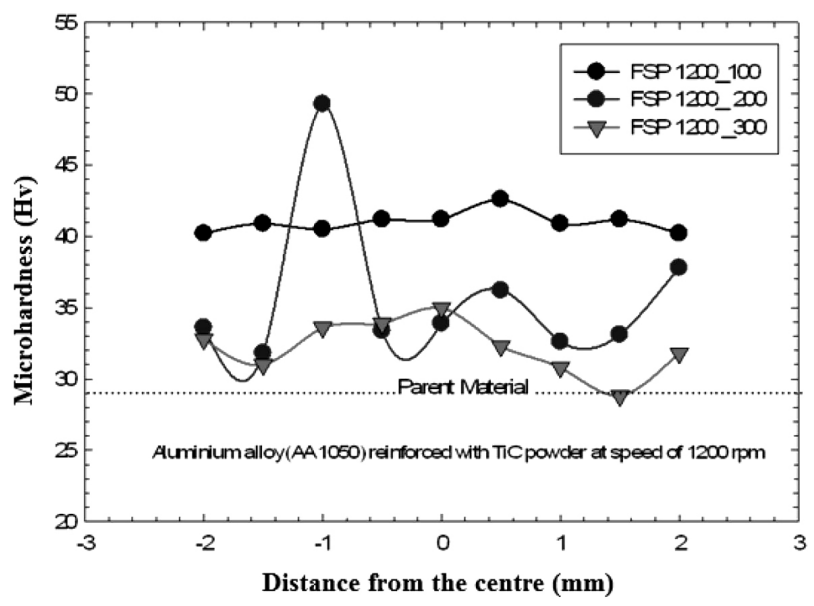

Figure 10: Vickers microhardness of friction-stir processed AA1050 reinforced with $\mathrm{TiC}$ powder processed at the rotational speed of 1200 $\min ^{-1}$ and different travel rates: the lower dashed line shows the parent material's condition

Slika 10: Vickers mikrotrdota predelanega AA1050 z mešanjem, s trenjem in ojačanega $\mathrm{s}$ TiC $\mathrm{v}$ prahu, obdelanega pri hitrosti vrtenja $1200 \mathrm{~min}^{-1}$ in različnih hitrostih premika: spodnja črtkana črta kaže pogoje pri izvorni zlitini

\subsection{Hardness profiling}

Figures 10 and 11 shows the Vickers microhardness of friction-stir processed AA1050 reinforced with TiC powder processed at the rotational speeds of $1200 \mathrm{~min}^{-1}$ and $1600 \mathrm{~min}^{-1}$, respectively, at different travel rates of (100, 200 and 300) $\mathrm{min}^{-1}$. The microhardness was measured on the matrices of the parent material and friction-stir processed materials with the lower dashed straight horizontal line indicating the homogeneity of the parent material. The hardness shows a significant improvement of the friction-stir processed material compared to the parent metal. The increase in the hardness can be attributed to the presence of the $\mathrm{TiC}$ particles in the matrix of the composite and the grain refinement of the matrix. The hardness across the friction-stir processed zone is not constant and the peak hardness value was observed at the point where the $\mathrm{TiC}$ was spotted. The average hardness values of the processed materials and the parent material are shown in Figure 11. The average hardness value of the parent materials is $28.9 \mathrm{HV}$ and the average hardness of the processed materials after using 1200) $\mathrm{min}^{-1}$ and at (100, 200 and 300$) \mathrm{mm} / \mathrm{min}$ are $(41,36$ and 32$) \mathrm{HV}$, respectively. The hardness results of the processed materials after using $1600 \mathrm{~min}^{-1}$ and at $(100,200$ and 300) $\mathrm{mm} / \mathrm{min}$ for processing were $(44,34$ and 32$) \mathrm{HV}$, respectively.

\subsection{Ultimate tensile strength}

D. Tabor ${ }^{29}$ has shown that the ratio of ultimate tensile strength (UTS) to the Vickers hardness is related to the strain hardening coefficient. The relation between these parameters was expressed using Equation (1):

$$
U T S=\left(\frac{H}{C}\right)(1-n)\left(\frac{12.5 n}{1-n}\right)^{n}
$$

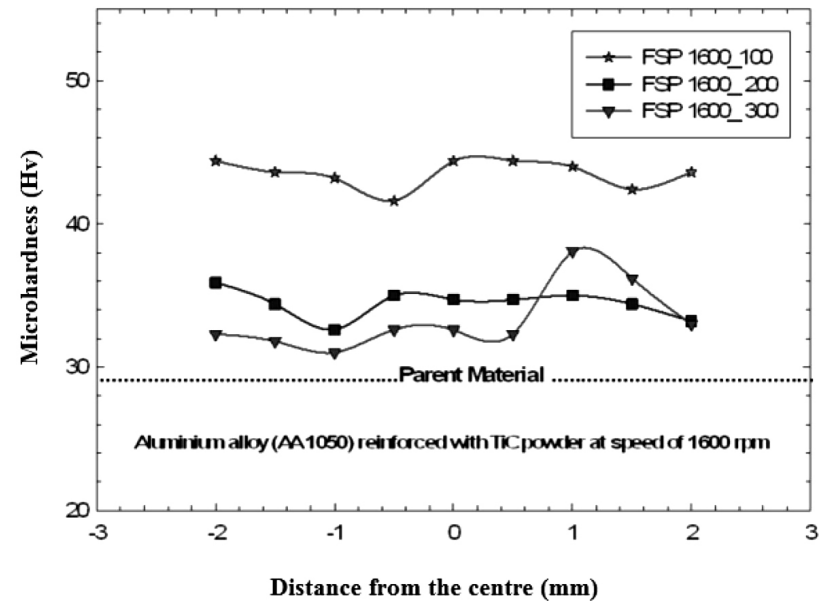

Figure 11: Vickers microhardness of friction-stir processed AA1050 reinforced with $\mathrm{TiC}$ powder processed at the rotational speeds of 1600 $\mathrm{min}^{-1}$ and different travel rates: the lower dashed line shows the parent material's condition

Slika 11: Vickers mikrotrdota obdelanega AA1050 z mešanjem s trenjem, ojačanega s TiC v prahu, obdelanega pri $1600 \mathrm{~min}^{-1}$ in pri različnih hitrostih pomikanja: nižja črtkana črta prikazuje osnovni material 
K. O. SANUSI, E. T. AKINLABI: FRICTION-STIR PROCESSING OF A COMPOSITE ALUMINIUM ALLOY (AA 1050) ...

Where UTS is the ultimate tensile strength, \# is the Vickers hardness, $n$ is the strain-hardening coefficient, and $C$ is a constant that has a value of 2.9 for mild steels and $\sim 3.0$ for copper alloys and aluminium. This relation was further improved by J. R. Cahoon ${ }^{30}$ in the form of Equation (2):

$$
U T S=\left(\frac{H}{2.9}\right)\left(\frac{n}{0.217}\right)^{n}
$$

where $H$ is the Vickers hardness and $n$ is the strainhardening coefficient.

Using Equation (2), the UTS were calculated and plotted in Figure 13. From Figure 13 it was observed that the parent material has a lower ultimate tensile strength compared to the materials processed by friction-stir processing reinforced with the TiC powder. It was also observed that the materials processed using rotational speeds of $1200 \mathrm{~min}^{-1}$ and $1600 \mathrm{~min}^{-1}$ and a travel rate of 100 have higher ultimate tensile strengths compared to the others. The trends in Figure $\mathbf{1 3}$ also correlate with the hardness results in Figure 12.

\subsection{Wear-volume losses}

The wear-volume loss of the samples after the wear test is shown in Figure $\mathbf{1 4}$ as a function of the process parameters for loads of $25 \mathrm{~N}$ with a sliding distance of $2000 \mathrm{~m}$. It has been shown theoretically that the mass loss can be estimated using the Archard Equation (3):

$$
V=K \frac{S L}{3 H}
$$

where $V$ is the volume worn away during testing, $S$ is the total sliding distance, $L$ is the normal load, $H$ is the hardness of the softer surface, and $K$ is a dimensionless wear coefficient specific to the sample under test. It is reasonable to expect from Equation (1) that the materials after FSP will experience a smaller mass loss

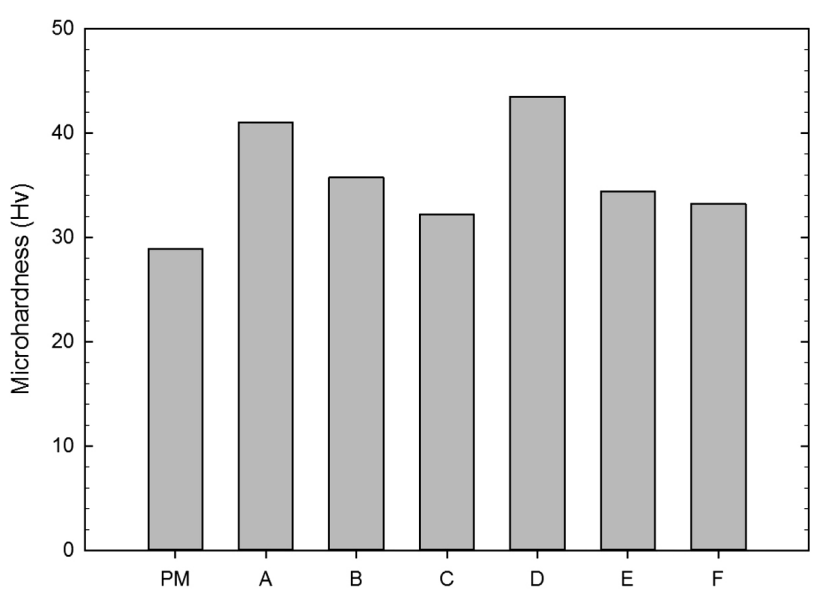

Figure 12: Average microhardness of parent material and friction-stir processed AA1050 reinforced with TiC powder

Slika 12: Povprečna mikrotrdota osnovnega materiala in AA1050, ojačanega s TiC v prahu po obdelavi z mešanjem s trenjem

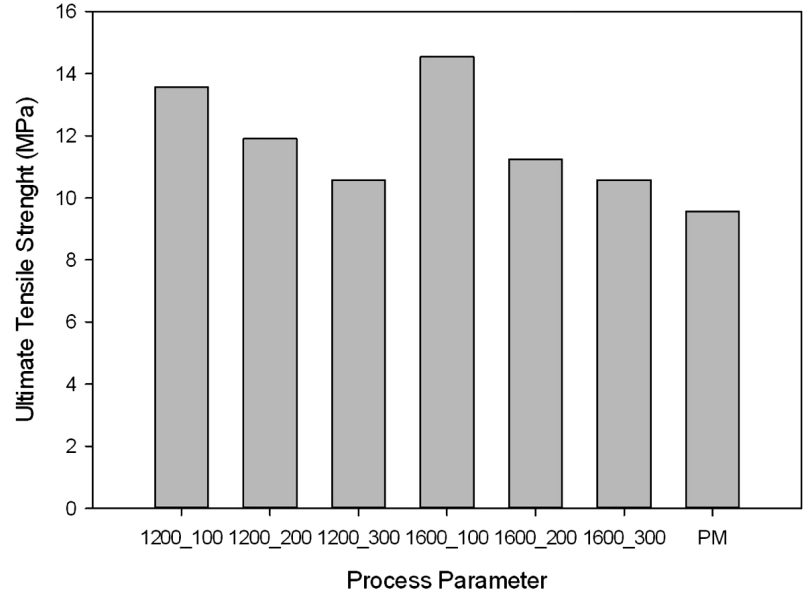

Figure 13: The ultimate tensile strength of parent material and friction-stir processed AA1050 reinforced with TiC powder

Slika 13: Natezna trdnost osnovnega materiala in AA1050 ojačanega s TiC, obdelanega z mešanjem s trenjem

and it shows in Figures $\mathbf{9}$ to $\mathbf{1 1}$ that the samples processed by FSP have a higher hardness than the parent material sample, which also shows in Figure 14 that the samples processed by FSP exhibit a lower mass loss compared to the parent material. Wear resistance is usually better for the MMC than the base metal for all the process parameters. This is due to the fact that the composite surface layer provides better wear resistance and it is harder than the base material.

The dimensional wear coefficient, $\mathrm{k}$, is widely used to compare the wear rates in different classes of materials and is defined by Equation (4):

$$
K=\frac{V}{S L}
$$

The calculation suggests that under a load of $25 \mathrm{~N}$ and at a $2000 \mathrm{~m}$ sliding distance, the dimensional wear coefficient for the samples processed and the parent

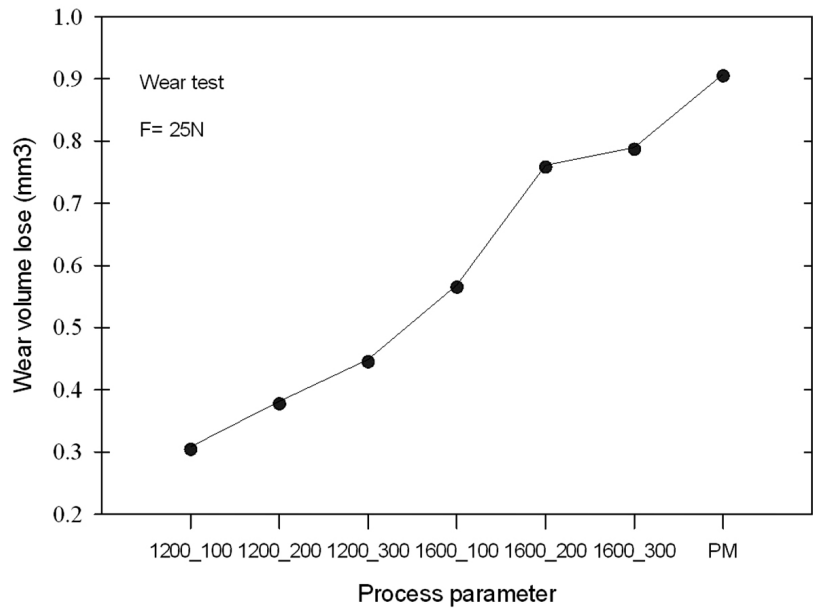

Figure 14: Wear-volume loss of processed samples for different parameters

Slika 14: Volumske izgube pri obrabi vzorcev, obdelanih z različnimi parametri 
material are shown in Table 3. These results confirm the feasibility of using FSP with larger bulk samples, especially for the optimization of surface properties such as the wear-resistance behaviour.

Table 3: Dimensional wear coefficient

Tabela 3: Koeficient dimenzijske obrabe

\begin{tabular}{|c|c|}
\hline Designation & $\begin{array}{c}\text { Dimensional wear coefficient } \\
\left(\mathrm{mm}^{2} \mathrm{~N}^{-1}\right)\end{array}$ \\
\hline FsP 1200_100 & $6.1712 \times 10^{-6}$ \\
\hline FsP 1200_200 & $7.6321 \times 10^{-6}$ \\
\hline FsP 1200_300 & $8.977 \times 10^{-6}$ \\
\hline FsP 1600_100 & $1.378 \times 10^{-5}$ \\
\hline FsP 1600_200 & $1.5227 \times 10^{-5}$ \\
\hline FsP 1600_300 & $1.580 \times 10^{-5}$ \\
\hline Parent Material & $1.815 \times 10^{-5}$ \\
\hline
\end{tabular}

\section{CONCLUSION}

In the present study, FSP was performed on an aluminium alloy (AA 1050) with $\mathrm{TiC}$ powder in order to investigate the evolving microstructural and mechanical properties. A surface composite layer was successfully fabricated on the aluminium sheets and the following conclusions were drawn from the test outcomes:

- The microstructural evolution of the AA1050 during FSP showed that the $\mathrm{TiC}$ particles were more uniformly distributed in the AA1050 after FSP using $1200 \mathrm{~min}^{-1}$ and at $100 \mathrm{~mm} / \mathrm{min}$, while at a high rotational speed of $1600 \mathrm{~min}^{-1}$, it was observed that the $\mathrm{TiC}$ particles were clustered in some parts of the stirred zone after the FSP.

- The hardness tests showed an improvement and an enhancement on the integrity of the processed materials due to the improvement in the evolving microstructure.

- The wear-resistance test results confirm the feasibility of using FSP for the optimization of surface properties of the composites produced.

\section{Acknowledgements}

The authors gratefully acknowledge the financial support of the National Research Foundation (NRF) South Africa, Faculty of Engineering and the Built Environment, University of Johannesburg, South Africa and the eNtsa Research Group of Nelson Mandela Metropolitan University (NMMU), Port Elizabeth, South Africa, for allowing us to use their facility. The Tertiary Education Support Programme of ESKOM South Africa and the University Research Committee (URC), University of Johannesburg, South Africa are acknowledged for the award of the research funds to support this study.

\section{REFERENCES}

${ }^{1}$ I. Galvao, A. Loureiro, D. Rodrigues, Influence of process parameters on the mechanical enhancement of copper-DHP by FSP, Advanced Materials Research, 445 (2012), 631-636, doi:10.4028/ scientific5/AMR.445.631

${ }^{2}$ R. Mishra, M. Mahoney, S. McFadden, N. Mara, A. Mukherjee, High strain rate superplasticity in a friction stir processed $7075 \mathrm{Al}$ alloy, Scripta Materialia, 42 (2000) 2, 163-168, doi:10.1016/S13596462(99)00329-2

${ }^{3}$ E. Akinlabi, R. Mahamood, S. Akinlabi, E. Ogunmuyiwa, Processing Parameters Influence on Wear Resistance Behaviour of Friction Stir Processed Al-TiC Composites, Advances in Materials Science and Engineering, (2014) 11

${ }^{4}$ P. Berbon, W. Bingel, R. Mishra, C. Bampton, M. Mahoney, Friction stir processing: a tool to homogenize nanocomposite aluminum alloys, Scripta Materialia, 44 (2001) 1, 61-66, doi:10.1016/S13596462(00)00578-9

${ }^{5}$ Z. Ma, R. Mishra, M. Mahoney, Superplastic deformation behaviour of friction stir processed 7075Al alloy, Acta materialia, 50 (2002) 17, 4419-4430, doi:10.1016/S1359-6454(02)00278-1

${ }^{6}$ P. Cavalierea, A. Squillace, High temperature deformation of friction stir processed 7075 aluminium alloy, Materials Characterization, 55 (2005), 136-142

${ }^{7}$ C. Chuang, J. Huang, P. Hsieh, Using friction stir processing to fabricate $\mathrm{MgAlZn}$ intermetallic alloys, Scripta Materialia, 53 (2005), 1455-1460, doi:10.1016/j.scriptamat.2005.08.019

${ }^{8}$ Y. Kwon, I. Shigematsu, N. Saito, Production of Ultra-Fine Grained Aluminum Alloy using Friction Stir Process, Materials Transactions, 44 (2003) 7, 1343-1350, doi:10.2320/matertrans.44.1343

${ }^{9}$ G. Minak, L. Ceschini, I. Boromei, M. Ponte, Fatigue properties of friction stir welded particulate reinforced aluminium matrix composites, International Journal of Fatigue, 32 (2010) 1, 218-226, doi:10.1016/j.ijfatigue.2009.02.018

${ }^{10}$ A. Thangarasu, N. Murugan, I. Dinaharan, S. Vijay, Microstructure and microhardness of AA1050/TiC surface composite fabricated using friction stir processing, Indian Academy of Sciences, 37 (2012) 5, 579-586

${ }^{11}$ D. B. Miracle, Metal matrix composites - From science to technological significance.,Composition Science Technology, 65 (2005), 2526-2540, doi:10.1016/j.compscitech.2005.05.027

${ }^{12}$ A. Kennedy, S. Wyatt, The effect of processing on the mechanical properties and interfacial strength of aluminium/TiC MMCs, Composites Science and Technology, 60 (2000), 307-314, doi:10.1016/ S0266-3538(99)00125-6

${ }^{13} \mathrm{~A}$. Mortensen, Interfacial phenomena in the solidification processing of metal matrix composites, Material Science Engineering, A135 (1991) 1-11, doi:10.1016/0921-5093(91)90527-T

${ }^{14}$ D. Lloyd, H. Lagace, A. McLeod, P. Morris, Microstructural aspects of aluminium-silicon carbide particulate composites produced by a casting method, Material Science Engineering, A 107 (1989), 73-80, doi:10.1016/0921-5093(89)90376-6

${ }^{15}$ E. Feest, Interfacial phenomena in metal-matrix composites, Composites, 25 (1994) 2, 75-86, doi:10.1016/0010-4361(94)90001-9

${ }^{16}$ O. Verezub, Z. Kálazi, A. Sytcheva, L. Kuzsella, G. Buza, N. Verezub, A. Fedorov, G. Kaptay, Performance of a cutting tool made of steel matrix surface nano-composite produced by in situ laser melt injection technology, Journal of Materials Process Technololgy, 211 (2011), 750-758, doi:10.1016/j.jmatprotec.2010.12.009

${ }^{17}$ T. Laha, A. Agarwal, T. McKechnie, S. Seal, Synthesis and characterization of plasma spray formed carbon nanotube reinforced aluminum composite, Materials Science Engineering, A 381 (2004), 249-25, doi:10.1016/j.msea.2004.04.014

${ }^{18}$ Y. Wang, X. Zhang, G. Zeng and F. Li, Cast sinter technique for producing iron base surface composites, Materials. Disposition, 21 (2000), 447-452 


\section{MATERIALI IN TEHNOLOGIJE/MATERIALS AND TECHNOLOGY (1967-2017) - 50 LET/50 YEARS}

\section{K. O. SANUSI, E. T. AKINLABI: FRICTION-STIR PROCESSING OF A COMPOSITE ALUMINIUM ALLOY (AA 1050) ...}

${ }^{19}$ E. Yun, K. Lee, S. Lee, Correlation of microstructure with high-temperature hardness of $(\mathrm{TiC}, \mathrm{TiN}) / \mathrm{Ti}-6 \mathrm{Al}-4 \mathrm{~V}$ surface composites fabricated by high-energy electron-beam irradiation, Surface Coat Technology, 191 (2005), 83-89, doi:10.1016/j.surfcoat.2004.02.040

${ }^{20}$ E. R. I. Mahmoud, K. Ikeuchi, M. Takahashi, Fabrication of $\mathrm{SiC}$ particle reinforced composite on aluminium surface by friction stir processing, Science Technology Weld Joining , 13 (2008), 607-618, doi:10.1179/136217108X333327

${ }^{21}$ E. R. I. Mahmoud, M. Takahashi, T. Shibayanagi, K. Ikeuchi, Effect of friction stir processing tool probe on fabrication of $\mathrm{SiC}$ particle reinforced composite on aluminium surface, Science Technology Weld Joining, 14 (2009), 413-425, doi:10.1179/136217109X406974

${ }^{22}$ R. Bauri, D. Yadav, G. Suhas, Effect of friction stir processing (FSP) on microstructure and properties of Al-TiC in situ composite, Materials Science and Engineering A, 528 (2011), 4732-4739, doi:10.1016/j.msea.2011.02.085

${ }^{23}$ A. Kahrizsangi, S. Kashani-Bozorg, Microstructure and mechanical properties of steel/TiC nano-composite surface layer produced by friction stir processing, Surface and Coatings Technology, 209 (2012), 15-22

${ }^{24}$ D. Yadav, R. Bauri, Nickel particle embedded aluminium matrix composite with high ductility, Materials Letters, 64 (2010) 6, 664-667, doi:10.1016/j.matlet.2009.12.030
${ }^{25}$ L. M. Marzoli, A. V. Strombeck, J. F. D. Santos, C. Gambaro, L. M. Volpone, Friction stir welding of an AA6061/A12O3/20p reinforced alloy, Composite Science Technology, 66 (2006), 363-371, doi:10.1016/j.compscitech.2005.04.048

${ }^{26}$ H. Nami, H. Adgi, M. Sharifitabar, H. Shamabadi, Microstructure and mechanical properties of friction stir welded $\mathrm{Al} / \mathrm{Mg} 2 \mathrm{Si}$ metal matrix cast composite, Materials Description, 32 (2010), 976-983

${ }^{27}$ L. Ceschini, I. Boromei, Minak, G, A. Morri, F. Tarterini, Effect of friction stir welding on microstructure, tensile and fatigue properties of the AA7005/10 vol. \% Al2O3p composite, Composite Science Technoology, 67 (2007), 605-615, doi:10.1016/j.compscitech.2006. 07.029

${ }^{28}$ Y. Yu Zhang, Y. Sato, H. Kokawa, S. H. Park, S. Hirano, Stir zone microstructure of commercial purity titanium friction stir welded using pcBN tool, Materials Science and Engineering: A, 488 (2008) 1-2, 25-30, doi:10.1016/j.msea.2007.10.062

${ }^{29} \mathrm{D}$. Tabor, The hardness and strength of metals, Journal Institute of Metals, 79 (1951), 1-18

${ }^{30}$ J. R. Cahoon, An improved equation relating hardness to ultimate strength, Metallurgical Transactions, 3 (1972) 11, 3040, doi:10.1007/BF02652880

${ }^{31}$ J. F. Archard, Contact and rubbing of flat surfaces, Journal of Applied Physic, 24, (1953), 981-988, doi:10.1063/1.1721448 